\title{
EFFICIENCY IMPROVEMENT IN INDUCTION MOTOR BY SLITTED TOOTH CORE DESIGN
}

\author{
Asim Gokhan Yetgin, Mustafa Turan
}

Original scientific paper In this study, a new design was suggested in order to improve the performance of induction motors. In the proposed design, slits were applied in the middle of stator and rotor teeth. In these slitted models, the depth and width of slits were optimized with Finite Element Method Magnetics (FEMM) software using Finite Elements Method (FEM). To show performance improvement, suggested motor model and a reference motor model were compared at the rated operating point for the values such as input and output power, input current, power factor, efficiency and losses. Because of the decreases in both iron and copper losses, total losses in motor were reduced and the efficiency for rated operating point was improved by $1,869 \%$. In the modelling, 3 $\mathrm{kW}$ squirrel-cage induction motor was used.

Keywords: induction motor efficiency; motor losses; slitted tooth core design

Porast učinkovitosti asinkronih motora pomoću dizajna jezgre s procijepljenim zubom

Izvorni zanstveni članak U ovom istraživanju predložen je novi dizajn kako bi se poboljšala učinkovitost rada asinkronih motora. U predloženom dizajnu primjenjeni su procijepi u sredini zubi statora i rotora. U ovim procijepljenim modelima dubina i širina procijepa su optimizirani uz pomoć programa Magnetska metoda konačnih elemenata (FEMM) i koristeći Metodu konačnih elemenata (FEM). Za prikaz poboljšanja izvedbe, predloženi model motora i referentni model motora su uspoređeni u definiranim pogonskim tačkama za vrijednosti kao što su ulazna i izlazna snaga, ulazna struja, faktor snage, efikasnost i gubitci. Zbog smanjenja gubitaka željeza i bakra, ukupni gubitak u motoru je smanjen, a povećana je efikasnost za definiranu pogonsku tačku za $1,869 \%$. U modeliranju korišten je $3 \mathrm{~kW}$ kavezni asinkroni motor.

Ključne riječi: efikasnost asinkronog morota; dizajna jezgre s procijepljenim zubom; gubitci motora

\section{Introduction}

Since induction motors are the most commonly used motors in industry, they form one of the major interest areas for the researchers both in dynamic and static state and the old discovered induction machine is still under improvement. Many different approaches have been applied in order to develop the performance of induction motor especially in the researches focused on the energy saving issues. It is possible to collect these approaches under four titles [1].

- Improving the performance with the works on stator and rotor slot shapes by using design software [2].

- Improving the performance with optimization methods such as finite elements method, artificial neural networks (ANN) and genetic algorithms (GA) $[3,4]$.

- Improving the performance by developing the materials used [5]

- Improving the performance by using magnetic barriers, cut-outs and slits [6].

Today several approaches have still been developed and various studies [7-12] have been carried out in order to develop the performance of induction motors. Kumar et al. [7] presented a new approach that minimizes copper $\&$ iron losses and optimizes the efficiency of a variable speed induction motor drive. Their method is based on a simple induction motor field oriented control model. It includes iron losses by using only conventional induction motor parameters. Sakthivel and Subramanian [8], in their paper, a model based on modified induction motor equivalent circuit, present a new application of particle swarm optimization (PSO) approach for field efficiency evaluation of induction motor. Delgado et al. [9] presented an optimization scheme without derivatives, called edge optimization, a simple off-line identification algorithm for an induction motor. The proposed approach relies on the information of a hard or soft start-up of the motor, in order to identify all seven induction motor parameters: stator and rotor leakage inductances, stator and rotor resistances, mutual inductance, mechanical inertia and friction coefficient. Faiz et al. [13] presented the negative effect of unbalanced voltage upon the losses and efficiency of an induction motor. Also they determined that the financial losses were caused by unbalanced voltage of the power supply using an analytical-statistical method. Donolo et al. [14] investigated the influence of voltage unbalance on the performance of induction motors. They use sequence equivalent circuits to determine the increase in losses of the induction motor. They analyse motors with open and closed rotor slots. Jabr and Kar [15] presented an experimental procedure to determine the machine parameters and saturation characteristics. The adopted experimental procedure facilitates the measurement of both stator and rotor leakage reactance saturation characteristics. Rasouli et al. [16] consider the identifiability of induction motor parameters, with a particular emphasis placed on using subset selection and shrinkage methods to allow the identification methods to focus on the most significant parameters.

Kostov et al. [17] presented an efficient approach for determining the equivalent circuit parameters of squirrel cage induction motors based on genetic algorithms. When three sets of data are used, the maximum relative error of the estimated parameters with regard to analytical values is less than $1 \%$.

Any study about performance improvement of the squirrel cage induction motor by using slitted structure has been found within the literature search except for the author's previous study given in $[18,19]$. 
Yetgin and Turan [19], in their study, the motor models reformed with the proposed shape design were analyzed with FEMM software program that uses finite elements method. It was found at the end of the analyses that when the optimum slit width value was $0,10 \mathrm{~mm}$, motor efficiency gave better results compared with other slit width values. The increase in slit width caused saturations in motor teeth and thus caused the motor efficiency to worsen. It was decided at the end of different modeling that the depth of the slits used in the proposed slitted motor models should be almost the same height as stator and rotor height.

In a loaded induction motor, rotor reaction will increase, causing an increase in leakage flux and decrease in coupling flux. In this study, slitted tooth design for induction motor was suggested to overcome negative effects of rotor reaction. By the suggested design, efficiency of induction motor has been improved without using higher grade laminations in induction motor.

\section{Calculation of losses}

Induction motors compose a large part of electric energy consumption of many countries. Therefore, determining the motor losses and improving the efficiency have recently been top priority for the manufacturers. We could analyse the losses in induction motor in two main components as constant losses and the losses changing with load. While constant losses are composed of iron, friction and windage losses, the losses changing with load include stator and rotor copper losses and additional load losses [20].

Stator and rotor copper losses can be calculated by Eq. (1). In the statements, $P_{\mathrm{Cu} 1}$ and $P_{\mathrm{Cu} 2}$ represent stator and rotor copper losses, $I_{1}$ stator current, $I_{2}$ rotor current referred to stator, $R_{1}$ and $R_{2}$ stator resistance and rotor resistance referred to stator.

$$
\begin{aligned}
& P_{\mathrm{Cu} 1}=3 I_{1}^{2} R_{1}, \\
& P_{\mathrm{Cu} 2}=3 I_{2}^{2} R_{2} .
\end{aligned}
$$

Iron losses occur in iron core and they are the functions of flux density, frequency and weight. Stator tooth losses $p_{\mathrm{t} 1}$ and stator yoke losses $p_{\mathrm{y} 1}$ are calculated with Eq. (2) and Eq. (3) respectively [21].

$$
\begin{aligned}
& p_{\mathrm{t} 1} \approx K_{\mathrm{t}} p_{10}\left(\frac{f_{1}}{50}\right)^{2} B_{\mathrm{ts}}^{x} G_{\mathrm{t} 1}, \\
& p_{\mathrm{y} 1} \approx K_{\mathrm{y}} p_{10}\left(\frac{f_{1}}{50}\right)^{1,3} B_{\mathrm{cs}}^{x} G_{\mathrm{y} 1} .
\end{aligned}
$$

In the above equations, $p_{10}$ stands for specific iron losses at $50 \mathrm{~Hz}$ and $1,5 T$ in terms of $\mathrm{W} / \mathrm{kg}, K_{\mathrm{t}}$ represent coefficient value for the machine construction which is between 1,6 and 1,8, $K_{\mathrm{y}}$ coefficient value for the machine construction which is between 1,6 and $1,9, G_{\mathrm{t} 1}$ stator teeth weight, $G_{\mathrm{y} 1}$ stator yoke weight, $B_{\mathrm{ts}}$ stator tooth flux density, $B_{\mathrm{cs}}$ stator yoke flux density and $f_{1}$ frequency. $x$ having a value between 1,5 and 2,5 is the material coefficient depending on lamination sheet material quality and operation point on magnetizing curve $[21,22]$.

The pulsation losses that occur in stator and rotor teeth are calculated with Eq. (4) [21].

$p_{\mathrm{pul}} \approx 0,5 \times 10^{-4}\left[\left(N_{\mathrm{r}} \frac{f_{1}}{p} K_{\mathrm{p} 1} B_{\mathrm{p} 1}\right)^{2} G_{\mathrm{t} 1}+\left(N_{\mathrm{s}} \frac{f_{1}}{p} K_{\mathrm{p} 2} B_{\mathrm{p} 2}\right)^{2} G_{\mathrm{t} 2}\right]$ (4)

In Eq. (4), $K_{\mathrm{p} 1}$ and $K_{\mathrm{p} 2}$ are the coefficients depending on the stator and rotor tooth flux density respectively. $B_{\mathrm{p} 1}$ and $B_{\mathrm{p} 2}$ are the coefficients depending on Carter coefficient. $G_{\mathrm{t} 2}, N_{\mathrm{s}}$ and $N_{\mathrm{r}}$ represent the rotor teeth weight, stator slot number and rotor slot number respectively.

Total iron losses $P_{\mathrm{Fe}}$ are calculated with the equation given below.

$P_{\mathrm{Fe}}=p_{\mathrm{t} 1}+p_{\mathrm{y} 1}+p_{\mathrm{pul}}$

Although additional load losses have constituted the subject of many studies [23, 24], they have not been modelled analytically. Additional load losses can be calculated by subtracting iron and copper losses from input power [25]. Some standards suggest various empirical factors. IEC 34-2 provokes a long lasting debate by allocating a fixed $0,5 \%$ of the rated input power to the additional load loss. NEMA MG1 recommends $1,2 \%$ for induction motors rated less than $2500 \mathrm{HP}(1864,25 \mathrm{~kW})$, and $0,9 \%$ for $2500 \mathrm{HP}(1864,25 \mathrm{~kW})$ and above. As an improvement, IEEE $112-\mathrm{El} / \mathrm{Fl}$ provides a variable portion of output power to additional load loss, depending on the machine ratings. Similarly, the new IEC standard 600342-1 provides a range of figures which is also a function of machine power ratings, as is plotted in [26].

In this study, additional load losses $\left(P_{\text {add }}\right)$ were obtained by subtracting all the calculated losses from input power. $P_{\text {in }}, P_{2}, P_{\mathrm{Fe}}, P_{\mathrm{Cu} 1}, P_{\mathrm{Cu} 2}$ and $P_{\mathrm{fw}}$ represent input power, output power, iron losses, stator copper losses, rotor copper losses and frictional and windage losses respectively in Eq. (6) [25, 27].

$P_{\mathrm{add}}=P_{\mathrm{in}}-\left(P_{2}+P_{\mathrm{Fe}}+P_{\mathrm{Cu} 1}+P_{\mathrm{Cu} 2}+P_{\mathrm{fw}}\right)$.

\section{Finite Element Method}

The finite element analysis (FEA) is an accurate and widely applied method in the study and simulation of electrical machines [28]. With the numerical magnetic field analysis, features which can be difficult, expensive or even impossible to measure can be explored. On the other hand, a simpler equivalent circuit model for the machine is required in many applications. The performance and applicability of the circuit model depend on both the structure of the model and the accuracy of the parameters. Besides an accurate simulation method, the FEA can be seen as a tool for obtaining the circuit parameters etc. [29].

In the last two decades, the developments in numerical methods and in computer have made it actical to use finite elements analysis to calculate the magnetic field in the electrical machines [30]. The FEA has many advantages compared to the other numerical methods such as handling complex geometries, nonlinearity etc. 
[31]. Therefore, FEA has been the most preferred numerical method in the analysis of the electrical motor. In various studies, it was expressed in detail how three phase induction machine could be modelled with FEA [32-37]. FEMM software using finite elements method uses Eq. (7) for the solutions of magneto static problems involving "B-H" characteristics that are not linear and the other analyses process is given in [38]. For modelling, the FEMM program (version 3.4) is used which is free package program. Dirichlet boundary condition is also used for the motor analyses.

$\nabla \times\left(\frac{1}{\mu(B)} \nabla \times A\right)=J \rightarrow J=-\frac{1}{\mu} \nabla^{2} A$.

In the Eq. (7), $J, B, A$ and $\mu$ present the current density, magnetic flux density, magnetic vector potential and magnetic permeability respectively.

\section{Proposed slitted construction}

In the proposed design, slits were applied in the middle of stator and rotor teeth. Reference motor model whose analysis was carried out with FEMM software is shown in Fig. 1 and the motor model on which the proposed slitted structure was applied is shown in Fig. 2. The analyses are carried out without changing the figures such as stator and rotor slot shapes, internal-external diameter, number of turns etc. The results and graphics are given for rated operating point.

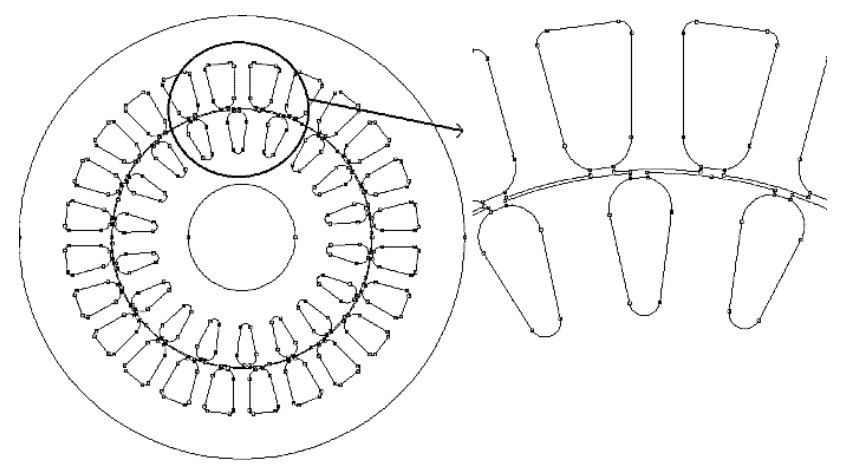

Figure 1 The reference motor (R.M.) model (without slits)

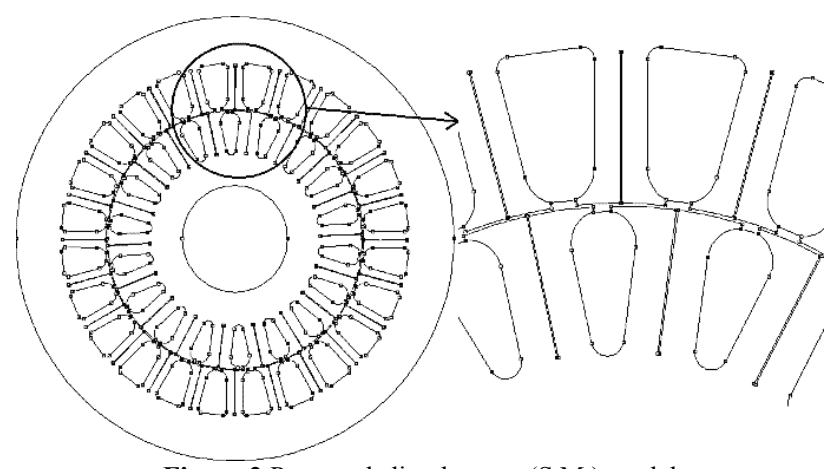

Figure 2 Proposed slitted motor (S.M.) model

\subsection{Advantages and disadvantages of proposed construction motor model}

The advantages of proposed slitted construction according to reference motor are given below [1]:
- The more effective using of the magnetic flux in core: reduction of saturation, better flux distribution at the teeth, reduction of rotor reaction.

- Increased zigzag path reluctance. That results in low additional losses.

- Decreased saturation. That results in reduced core loss.

- Smaller slip. That causes less rotor copper loss.

- Lowered total losses. That results in better efficiency.

- Improved overall performance on the rated operating point.

- Smaller leakage reactance. That results in a better speed-torque characteristic.

- Increased power factor. That causes improvement in reactive power consumption.

The disadvantage of the proposed slitted construction is given below:

- For small power motors, the initial construction cost is slightly high owing to cut off the core with laser.

\subsection{The opening of the slits}

In proposed design, slits on the teeth of rotor and stator can be machined by laser cutting, wire cut EDM (Electric Discharge Machining) or water jet cutting machines. Sheets for small horsepower motors can be cut one by one or multiple at once up to $20 \mathrm{~mm}$ thicknesses. In application of proposed slitted design to high power motors, it is more convenient to use die cutting technics. Since stamping die mould is manufactured once, there will be no additional costs for high power motors in mass production.

Name plate values of reference motor are given in Tab. 1.

Table 1 Parameters of the induction motor

\begin{tabular}{|l|c|c|}
\hline \multicolumn{1}{|c|}{ Motor parameters } & Symbol & Value \\
\hline Rated power / kW & $P_{\mathrm{n}}$ & 3 \\
\hline Rated voltage / V & $U_{1}$ & 380 \\
\hline Rated current / A & $I_{\mathrm{n}}$ & 6,63 \\
\hline Connection type & - & Star \\
\hline Frequency / Hz & $f_{1}$ & 50 \\
\hline Number of phase & $m$ & 3 \\
\hline Power factor & $\cos \varphi$ & 0,88 \\
\hline
\end{tabular}

In the proposed models, slit depths were chosen as $6,25 \mathrm{~mm}, 7,5 \mathrm{~mm}, 11,25 \mathrm{~mm}, 13,125 \mathrm{~mm}, 15 \mathrm{~mm}, 16,875$ $\mathrm{mm}, 18,75 \mathrm{~mm}, 19,6 \mathrm{~mm}, 21 \mathrm{~mm}$ and $23 \mathrm{~mm}$ where the slit widths were changing as $0,09 \mathrm{~mm}, 0,1 \mathrm{~mm}, 0,15 \mathrm{~mm}$, $0,25 \mathrm{~mm}, 0,5 \mathrm{~mm}, 1 \mathrm{~mm}, 1,5 \mathrm{~mm}$ and 2,5 mm. For each slit depth with corresponding slit widths FEMM models are constructed. In this manner, the process has been carried out on 56 different designs [19].

After having various modelling for slitted core design, it is concluded that optimal heights of slits are at the heights of slots and optimal width of slits is $0,1 \mathrm{~mm}$ that is the value to beware of saturation and to keep zigzag leakage flux low $[1,18]$.

The leakage inductances of stator and rotor, the zigzag flux changes and distribution of the magnetic vector potential for both the reference and slitted motor are given in [18]. Coupling flux for different core points 
was obtained and the magnetic flux and magnetization inductance values are also given in details in [18].

In Tab. 2, output power, current, power factor, torque, efficiency and relative differences obtained from the rated operating point of slitted structure motor and reference motor models were presented. The slitted motor model which has a slit width of $0,1 \mathrm{~mm}$ and slit depth of 15,00 $\mathrm{mm}$ and reference motor were compared. The obtained values from FEMM which are stator and rotor resistance values, mutual inductance value, time constant value, magnetic flux density values etc. were adapted to Matlab Software. Matlab outputs are given in Tab. 2. In calculations, number of decimal places is chosen with 12 digits.

Table 2 Rated operating values and relative differences for reference and slitted motor models [1]

\begin{tabular}{|l|c|c|c|}
\hline Parameters of motor & $\begin{array}{c}\text { Reference } \\
\text { motor }\end{array}$ & $\begin{array}{c}\text { Slitted } \\
\text { motor }\end{array}$ & $\begin{array}{c}\text { Relative } \\
\text { difference / \% }\end{array}$ \\
\hline Output power / W & 3030,0 & 3089,0 & 1,947 \\
\hline Efficiency / \% & 78,965 & 80,441 & 1,869 \\
\hline Current / A & 6,645 & 6,613 & $-0,481$ \\
\hline Power factor / - & 0,875 & 0,880 & 0,571 \\
\hline Torque / N·m & 10,223 & 10,632 & 4,000 \\
\hline
\end{tabular}

From Tab. 2, it is seen that the efficiency, output power and power factor values obtained from slitted structure motor model increased. The rated torque obtained from slitted motor model increased by $4 \%$ compared to the torque value of reference motor and therefore the output power increased. The efficiency increased by $1,869 \%$ as a result of the increase in output power by $1,947 \%$. A $0,481 \%$ decrease was yielded in the current depending on the increase in the magnetizing impedance. The input power value slightly increased, because of increase in power factor.

All the lost power and relative differences obtained for reference and slitted motor models are presented in Tab. 3. The lost power ingredients were calculated by Matlab software using the result of FEMM analysis.

Table 3 Lost power and relative differences for reference and slitted motor models [1]

\begin{tabular}{|l|c|c|c|}
\hline & $\begin{array}{c}\text { Reference } \\
\text { motor }\end{array}$ & $\begin{array}{c}\text { Slitted } \\
\text { motor }\end{array}$ & $\begin{array}{c}\text { Relative } \\
\text { difference / \% }\end{array}$ \\
\hline \multicolumn{1}{|c|}{ Motor losses } & \multicolumn{2}{|c|}{ Values / W } & \\
\hline Stator copper & 164,388 & 162,052 & $-1,417$ \\
\hline Rotor copper & 162,834 & 160,458 & $-1,456$ \\
\hline Stator tooth & 95,507 & 68,611 & $-28,161$ \\
\hline Rotor tooth & 1,903 & 1,761 & $-7,368$ \\
\hline Stator yoke & 260,776 & 246,088 & $-5,632$ \\
\hline Pulsation & 3,766 & 3,714 & $-1,380$ \\
\hline Additional & 28,426 & 18,595 & $-34,584$ \\
\hline Friction \& windage & 90,0 & 90,0 & - \\
\hline Total & 807,6 & 751,3 & $-6,971$ \\
\hline
\end{tabular}

There was not much change in stator and rotor copper losses since no changes were made for windings in the modelling. But, slight decrease was observed because of lowered current.

Stator tooth loss obtained for slitted motor showed $28,161 \%$ decrease compared with reference motor model. The first reason of this was $1,870 \%$ decrease occurring in the stator tooth weight. The second and major reason was decrease in magnetic flux density observed in these parts, since quadrature axis flux has decreased as a result of decrease in rotor reaction. Although the slitted structured motor and reference motor have the same weight, 5,632\% decrease was gained in stator yoke losses since there was some decrease in magnetic flux density in the slitted structured motor.

Rotor tooth losses were decreased since rotor had smaller frequency for the same output power. Furthermore, another important point was the decrease in the additional load losses. $6,971 \%$ gain was yielded from the slitted structured motor model in total losses in comparison with the reference model motor. 1,869\% improvement was observed in efficiency for slitted motor model because of the decreases in losses in comparison with the reference motor model.

Fig. 3 and Fig. 4 illustrate the magnetic flux density distribution of the reference and the slitted motor models.

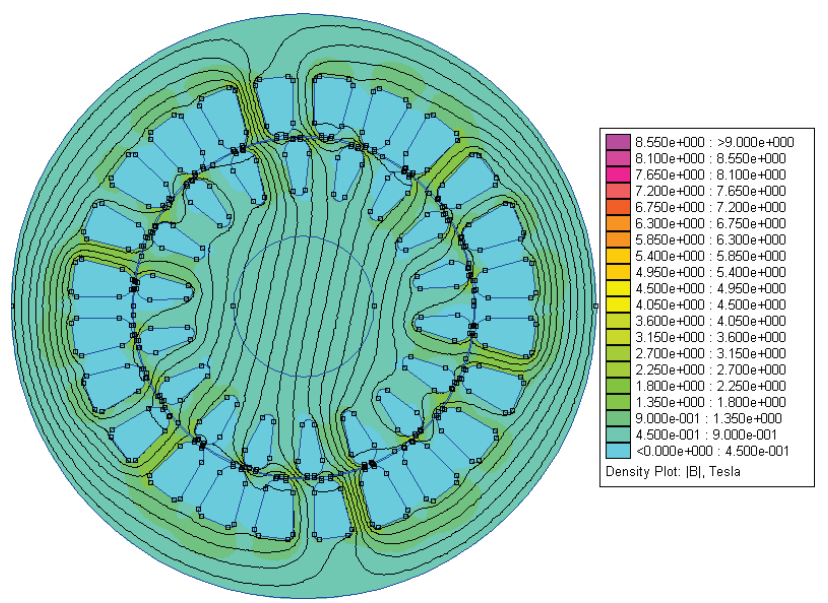

Figure 3 Magnetic flux density distribution of the reference motor model

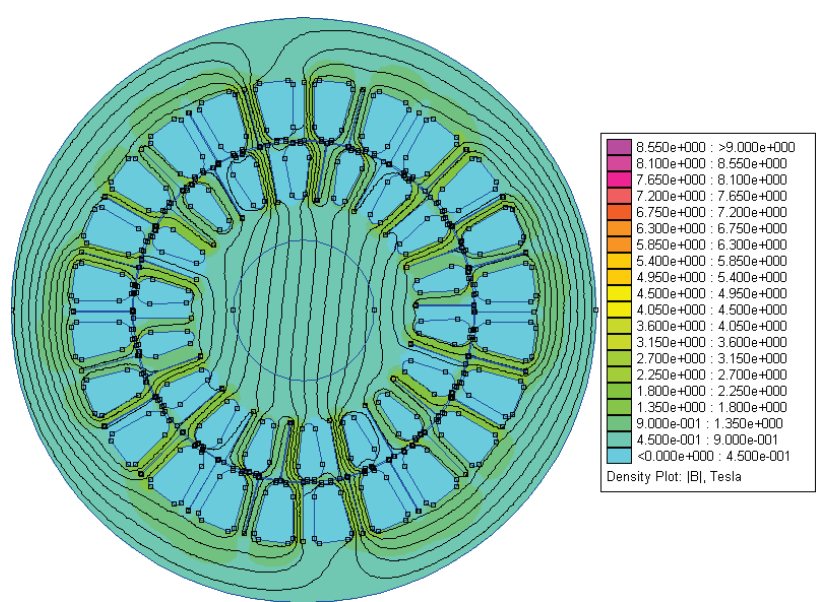

Figure 4 Magnetic flux density distribution of the slitted motor model which has $15,00 \mathrm{~mm}$ slit depth and $0,1 \mathrm{~mm}$ slit width

It can be easily seen from the figures that magnetic field distribution in slitted motor model is more conditioned. Magnetic flux density in teeth and yoke parts of stator and rotor is lower than the reference motor's. However, magnetic flux density near the teeth tips in slitted model is higher than the reference motor's. This can be corrected by rounding slit tips.

Stator and rotor tooth and stator yoke weights and the relative values according to the reference motor model are presented in Tab. 4. 
Table 4 Core weight and relative differences for reference and slitted motor models [1]

\begin{tabular}{|l|c|c|c|}
\hline & $\begin{array}{c}\text { Reference } \\
\text { motor }\end{array}$ & Slitted motor & $\begin{array}{c}\text { Relative } \\
\text { difference / \% }\end{array}$ \\
\hline \multicolumn{1}{|c|}{ Parameters } & \multicolumn{2}{|c|}{ Weight / kg } & \\
\hline Stator tooth & 2,2990 & 2,2560 & $-1,870$ \\
\hline Stator yoke & 6,7904 & 6,7904 & - \\
\hline Rotor tooth & 2,6545 & 2,6185 & $-1,356$ \\
\hline Total & 11,7439 & 11,6649 & $-0,672$ \\
\hline
\end{tabular}

Stator and rotor tooth weights decreased by $1,870 \%$ and $1,356 \%$ for slitted motor model respectively. Total weight was decreased by $0,672 \%$ in slitted motor model.

The speed-efficiency curves for reference and slitted motor models are presented in Fig. 5. The figure shows that slitted core motor model exhibits a better efficiency distribution, especially around rated operating speed.

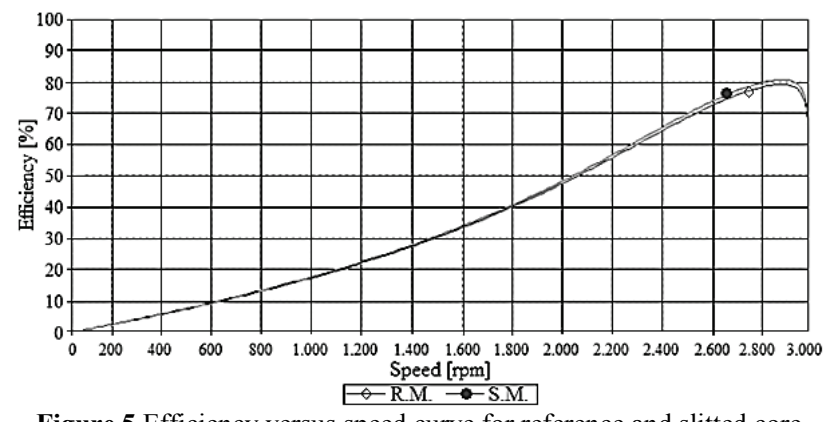

Figure 5 Efficiency versus speed curve for reference and slitted core motor models

In Fig. 6a and 6b, the efficiency and relative difference values for reference and slitted motors at rated operating point are presented [1].
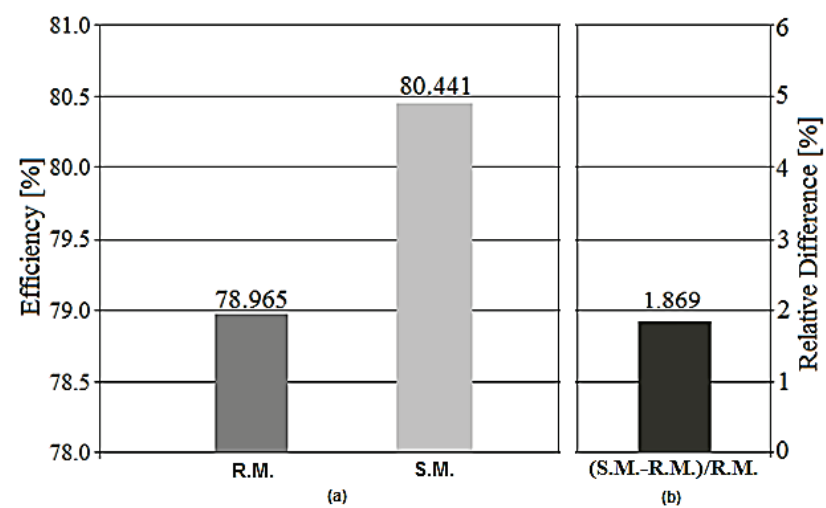

Figure 6 (a) Efficiency and (b) relative difference values for reference and slitted motor models

For the slitted motor model, the efficiency value is obtained by $1.869 \%$ higher than the reference motor model because of the reduced losses and the improved output power values.

\section{Conclusions}

In this study, a new slitted tooth design was suggested in order to increase the performance of induction motor. The motor models created with the suggested design were analysed with FEMM software using finite elements method and the following results were obtained.

In the proposed design, $11,542 \%$ decrease in iron losses was obtained as a result of decreased local flux density due to flux conditioning and lowered core volume.

Because of the decreases in both iron and copper losses, total losses in motor were reduced and the efficiency for rated operating point was improved by $1,869 \%$. Also, a small improvement in reactive power consumption for slitted core motor was yielded as a result of $0,571 \%$ increase in power factor.

It can be said that the proposed slitted core design decreased worse rotor reaction effects by conditioning teeth flux. Thus, additional load losses or stray losses are also reduced by $34,584 \%$. Slitted core design benefits discussed all performance parameters of motor. To beware of saturation in teeth, slit width must be chosen properly small.

\section{Acknowledgements}

This work was supported by Sakarya University Scientific Research Project.

\section{References}

[1] Yetgin, A. G. Performance Improvement of Induction Motor with SlittedCore Design. // PhD Thesis, Department of Electrical-Electronics Engineering, Sakarya, Turkey, 2010.

[2] Sundaram, M.; Navaneethan, P. On the influence of stator slot shape on the energy conservation associated with the submersible induction motors. // American Journal of Applied Sciences. 8, 4(2011), pp. 393-399. https://doi.org/10.3844/ajassp.2011.393.399

[3] Cunkas, M. Intelligent design of induction motors by multiobjective fuzzy genetic algorithm. // Journal of Intelligent Manufacturing. 21, 4(2010), pp. 393-402. https://doi.org/10.1007/s10845-008-0187-0

[4] Kentli, F. A survey on design optimization studies of induction motors during the last decade. // Istanbul University Journal of Electrical \& Electronics Engineering. 9, 2(2009), pp. 969-975.

[5] Manoharan, S.; Devarajan, N.; Deivasahayam, S. M.; Ranganathan, G. Review on efficiency improvement in squirrel cage induction motor by using DCR technology. // Journal of Electrical Engineering. 60, 4(2009), pp. 227-236.

[6] Aho, T.; Nerg, J.; Pyrhönen, J. The Effect of the Number of Rotor Slits on the Performance Characteristics of MediumSpeed Solid Rotor Induction Motor. // The 3rd IET Int. Conference Power Electronics, Machines and Drives / Dublin, 2006, pp. 515-519. https://doi.org/10.1049/cp:20060162

[7] Kumar, K. R.; Sakthibala, D.; Palaniswami, S. Efficiency optimization of induction motor drive using soft computing techniques. // International Journal of Computer Applications. 3, 1(2010), pp. 6-12. https://doi.org/10.5120/703-986

[8] Sakthivel, V. P.; Subramanian, S. On-site efficiency evaluation of three-phase induction motor based on particle swarm optimization. // Energy, 36(2011), pp. 1713-1720. https://doi.org/10.1016/j.energy.2010.12.057

[9] Delgado, D. U. C.; Santana, E. R. A.; Trejo, D. R. E. Edge optimisation for parameter identification of induction motors. // IET Electric Power Applications. 5, 8(2011), pp. 668-675. https://doi.org/10.1049/iet-epa.2010.0192

[10] Matic, P.; Vukosavic, S. N. Voltage angle direct torque control of induction machine in field-weakening regime. // IET Electric Power Applications. 5, 5(2011), pp. 404-414. https://doi.org/10.1049/iet-epa.2010.0214 
[11] Mohanty, K. B.; Singh, M. Performance improvement of induction motor drive using feedback linearization and fuzzy torque compensator with RTDS implementation. // International Review of Electrical Engineering. 7, (2012), pp. 4374-4382.

[12] Dandil, B.; Tuncer, S. Four-quadrant control of multilevel inverter fed induction motor drives. // Journal of Scientific \& Industrial Research. 67, (2008), pp. 688-696.

[13] Faiz, J.; Ebrahimpour, H.; Pillay, P. Influence of unbalanced voltage supply on efficiency of three phase squirrel cage induction motor and economic analysis. // Energy Conversion and Management. 47, (2006), pp. 289302. https://doi.org/10.1016/j.enconman.2005.04.009

[14] Donolo, P.; Bossio, G.; De Angelo, C. Analysis of voltage unbalance effects on induction motors with open and closed slots. //Energy Conversion and Management. 52, (2011), pp. 2024-2030. https://doi.org/10.1016/j.enconman.2010.10.045

[15] Jabr, H. M.; Kar, N. C. Leakage flux saturation effects on the transient performance of wound-rotor induction motors. // Electric Power Systems Research. 78, (2008), pp. 12801289. https://doi.org/10.1016/j.epsr.2007.11.004

[16] Rasouli, M.; Westwick, D. T.; Rosehart, W. D. Reducing induction motor identified parameters using a nonlinear lasso method. // Electric Power Systems Research. 88(2012), pp. 1-8. https://doi.org/10.1016/j.epsr.2012.01.011

[17] Kostov, I.; Spasov, V.; Rangelova, V. Application of genetic algorithms for determining the parameters of induction motors. // Technical Gazette. 16, 2(2009), pp. 4953.

[18] Yetgin, A. G.; Turan, M.; Canakoglu, A. I. A novel slitted tooth core design to decrease leakage flux in induction motor. // Journal of the Faculty of Engineering and Arcchitecture of Gazi University. 27, 3(2012), pp. 607-614.

[19] Yetgin, A. G.; Turan, M. Efficiency optimization of slittedcore induction motor. // Journal of Electrical Engineering. 65, 1(2014), pp. 60-64. https://doi.org/10.2478/jee-2014-0009

[20] Timmer, R.; Helinko, M.; Eskola, R. Motor efficiency, focus on optimizing lifetime performance on motors. ABB Review. 2007.

[21] Boldea, I.; Nasar, S. A. The Induction Machine Handbook. CRC Press LLC, 2002.

[22] Mergen, A. F.; Zorlu, S. Electrical Machines II, Induction Machine. Birsen Publishing, Istanbul, 2005.

[23] Cao, W.; Bradley, K. J.; Allen, J. Evaluation of additional loss in induction motors consequent on repair and rewinding. // IEE Proceeding Electric Power Application. 153, 1(2006), pp. 1-6. https://doi.org/10.1049/ip-epa:20050144

[24] Hussein, E.; Mutschler, P. Optimal Flux Loss Model based of Speed SensorlessVector Control Induction Motor. // 5th IET Int. Conference Power Electronics, Machines and Drives (PEMD 2010) / UK, 2010, pp. 1-6. https://doi.org/10.1049/cp.2010.0005

[25] Renier, B.; Hameyer, K.; Belmans, R. Comparison of standards for determining efficiency of three phase induction motors. // IEEE Transactions on Energy Conversion. 14, 3(1999), pp. 512-517. https://doi.org/10.1109/60.790906

[26] Cao, W.; Bradley, K. J.; Clare, J. C.; Wheeler, P. W. Comparison of stray load and inverter-induced harmonic losses in induction motors using calorimetric and harmonic injection methods. // IEEE Transactions on Industry Applications. 46, 1(2010), pp. 249-255. https://doi.org/10.1109/TIA.2009.2036675

[27] Corino, S.; Romero, E.; Mantilla, L. F. How the Efficiency of Induction Motor is Measured?

[28] Holik, P. J.; Holik, S. M. A Finite-Element Model for Induction Machines Incorporating Winding Faults. // 5th IET Int. Conference Power Electronics, Machines and Drives (PEMD 2010) / UK, 2010, pp. 1-3. https://doi.org/10.1049/cp.2010.0086
[29] Repo, A. K.; Arkkio, A. Numerical impulse response test to identify parametric models for closed-slot deep-bar induction motors. // IET Electric Power Applications. 1, 3(2007), pp. 307-315. https://doi.org/10.1049/iet-epa:20060436

[30] Islam, M. J.; Pippuri, J.; Perho, J.; Arkkio, A. Timeharmonic finite-element analysis of eddy currents in the form-wound stator winding of a cage induction motor. // IET Electric Power Applications. 1, 5(2007), pp. 839-846. https://doi.org/10.1049/iet-epa:20070138

[31] Ergene, L. T.; Salon, S.; Akiyama, J. Y. Calculation of the Rotor Bar Resistance and Leakage Inductance in a SolidRotor Induction Motors with a One Slot Model. // 14th Compumag Conference / New York, 2003, pp 1-2.

[32] Dorrel, D. G.; Holik, P. J.; Thougaardt, H. J.; Jensen, F.; Lombard, P. Modelling Axial Variations in Induction Motors with Rotor Skew using Multi-Sliced 2D Finite Element Analysis. // The 3rd IET Int. Conference Power Electronics, Machines and Drives (PEMD 2006) / Dublin, 2006, pp. 686-690. https://doi.org/10.1049/cp:20060196

[33] Islam, M. J.; Arkkio, A. Effects of pulse-width-modulated supply voltage on eddy currents in the form-wound stator winding of a cage induction motor. //IET Electric Power Applications. 3, 1(2009), pp. 50-58. https://doi.org/10.1049/iet-epa:20080060

[34] Islam, M. J.; Arkkio, A. Time-stepping finite-element analysis of eddy currents in the form-wound stator winding of a cage induction motor supplied from a sinusoidal voltage source. // IET Electric Power Applications. 2, 4(2008), pp. 256-265. https://doi.org/10.1049/iet-epa:20070440

[35] Jorks, H.; Gjonaj, E.; Weiland, T. Simulation of an Induction Motor Including Eddy-Current Effects in Core Laminations. // IET 8th Int. Conference in Computation in Electromagnetics (CEM 2011) / Poland, 2011, pp. 54-55. https://doi.org/10.1049/cp.2011.0034

[36] Henrotte, F.; Heidt, J.; Lange, E.; Van der Giet, M.; Hameyer, K. Extraction from field models of the lumped parameters of induction motors. // IET Science, Measurement and Technology. 2, 6(2008), pp. 447-454. https://doi.org/10.1049/iet-smt:20080088

[37] Diaz, G.; Arboleya, P.; Moran, C. G.; Aleixandre, J. G. Revision of the hysteresis and excess loss computation method as a means of improving the rotational loss estimate in induction motors. // IET Electric Power Applications. 1, 1(2007), pp. 75-81. https://doi.org/10.1049/iet-epa:20060169

[38] Meeker, D. Finite Element Method Magnetics. User's Manuel. 2006.

\section{Authors' addresses}

\section{Asst. Prof. Asim Gokhan Yetgin, PhD}

Electrical \& Electronics Engineering Department, Dumlupinar University, Evliya Celebi Campus, 43100 Kutahya, Turkey Tel: 0264-2652031 / 4273

E-mail: gokhan.yetgin@dpu.edu.tr

\section{Asst. Prof. Mustafa Turan, PhD}

Electrical \&Electronics Engineering Department, Sakarya University,

Esentepe Campus, 54050 Serdivan/Sakarya, Turkey Tel: 0264-2955454

E-mail: turan@sakarya.edu.tr 